\title{
Effect of Feeding Graded Levels of Wild Silver Leaf Desmodium (Desmodium Uncinatum) on Growth and Bodyweight Change of Horro Sheep Fed Basal Diet of Natural Pasture Hay
}

\author{
Jalel Fikadu Yadeta ${ }^{1}$ Dr. Mangistu Urge Leta ${ }^{2}$ \\ 1.Assosa University, College of Agriculture and Natural Resources, PO. Box18, Assosa, Ethiopia \\ 2.Haramaya University, School of animals and Range Sciences P.O. Box137, Diredawa, Ethiopia
}

\begin{abstract}
This experiment was conducted at Nedjo ATVET College with the objective of evaluating the effects of graded levels of wild silver leaf desmodium (Desmodium uncinatum) on growth and body weight change Horro sheep fed a basal diet of natural pasture hay. Twenty intact male Horro sheep with intact milk teeth and an average initial weight of $18.28 \pm 1.47 \mathrm{~kg}$ (mean \pm SD) were used. The experimental sheep were blocked into 5 blocks of 4 animals based on initial body weight and randomly assigned to one of the four treatments within a block. The treatments were natural pasture hay ad libitum $\left(\mathrm{T}_{1}\right)$ and wild silver leaf desmodium supplement at levels of $200\left(\mathrm{~T}_{2}\right), 300\left(\mathrm{~T}_{3}\right)$, $400\left(\mathrm{~T}_{4}\right) \mathrm{g} / \mathrm{head} / \mathrm{d}$ on dry matter bases. The basal diet had DM, CP and OM of 91.2, 75.5 and 9.3 , respectively while the corresponding values for Desmodium were 89.8, 77.8 and 16.8. Desmodium supplementation resulted in significantly higher $(\mathrm{p}<0.01)$ final body weight and average daily gain $\left(15.6,38.9,45.6\right.$ and $68.9 \mathrm{~g} / \mathrm{d}$ in $\mathrm{T}_{1}, \mathrm{~T}_{2}, \mathrm{~T}_{3}$ and $T_{4}$ respectively $)(p<0.001)$ than the sheep in the control treatment. Therefore, supplementation with $400 \mathrm{~g} / \mathrm{d}$ Desmodium improved body weight of sheep and correspondingly increased the net income from the sale of sheep at the end of the feeding trial. Therefore, in the present study supplementation of wild silver leaf desmodium to natural grass hay at $400 \mathrm{~g}$ appears to be the best level for Horro sheep in growth and daily body gain.
\end{abstract}

Keywords: body gain, sheep, Legumes and desmodium

DOI: $10.7176 / \mathrm{JBAH} / 10-17-05$

Publication date:September $30^{\text {th }} 2020$

\section{INTRODUCTION}

Ethiopia has a diverse indigenous sheep population, numbering 25.5 million head (CSA, 2013), in parallel with its diverse ecology, production systems and ethnic communities. Sheep contribute about $20 \%$ of all domestic meat consumption and are a major source of earnings through the sale of live animals and skins. With high reputation in international markets for some natural characteristics of clarity, thickness, flexibility, strength and compact texture which make them especially suitable for high quality gloves, sports equipment and garments, Ethiopian highland sheepskins, the largest volume of which comes from Oromia Region, are the major sources foreign earnings obtained from the leather sector.

Livestock in Ethiopia are an important and integral component of agriculture, which is the backbone of the economy. These sub-sectors do not only provide animal protein for the ever escalating human population, but also contribute in providing export commodities, such as live animals, hides and skins products serving as a source of foreign exchange earning to the country (CSA, 2004). However, productivity is very low and lags behind the growth of the population. This leads to a net decline in per capita consumptions of livestock products. The average per capita annual consumption of meat and dairy products are just $4.6 \mathrm{~kg}$ and $16.7 \mathrm{~kg}$, respectively (Kibrom and Ibrahim 2012). Given the recent growth in income, there is potential for growth in the demand for livestock products. This requires increased livestock production and productivity in the future.

Sheep are a source of risk mitigation during crop failures, of property security and of monetary saving and investment in addition to many other socio economic and cultural functions (Markos, 2006). The productivity of indigenous sheep breed is low as compared to temperate breeds due to limited genetic capacity and mainly environmental factors. Among the environmental factors, the main bottleneck for the poor animal production in numerous African and Asian countries is the inadequate supply and low level of feeding due to serious shortage of feedstuffs. Ben Salem et al. (2003) reported that there is a wide gap between the requirements and supplies of nutrients for small ruminants in numerous African and Asian countries. The contributing factors to this gap are higher number of animals in relation to grazing areas, unreliable rainfall, increasing human population, small land holding and decreasing land productivity. In addition to scarcity of feed, sheep productivity is constrained by diseases, lack of infrastructure, market information and trained personnel (Markos, 2006). The major feed resources for small ruminants in Ethiopia are forage from natural pastures hay grass, and legumes. Legumes can contribute to a better utilization of natural pasture hay. They are rich in protein (both fermentable and by-pass protein depending upon the level of tannin content) and other nutrients such as minerals. The amount of forage legumes needed to provide effective supplementation could vary with the quality of the basal diet and the quality of the supplement. In the present study area, wild desmodium (Desmodium uncinatum cv. Silver leaf) is naturally 
gown and is widely used by farmers as feed resource for animals either as grazing or hay forage. However, effect of feeding this legume on growth and body weight gain of sheep has not been evaluated for its proper utilization. The present study was therefore designed with the following objectives.

\section{Objective of the study}

$>$ to evaluate growth and body weight change of Horro sheep fed a basal diet of natural pasture hay and supplemented with graded levels of Silver leaf desmodium (Desmodium uncinatum)

\section{MATERIALS AND METHODS}

\section{Experimental Feeds and Feeding}

Wild silver leaf desmodium and natural pasture hay were harvested from the campus of Nedjo ATVET College. The Desmodium was grown naturally under the coffee plant, at the edge of crop farm and livestock protected areas. Desmodium and hay was chopped to an approximate size of $5 \mathrm{~cm}$ for ease of consumption by animals, dried under shade on a plastic sheet and stored at the experimental site. The animal was offered natural pasture hay as a basal diet, common salt as mineral lick, and water ad libitum. The desmodium was given according to the treatments and offered to the animals in two equal halves at 0800 and 1600 hours daily.

\section{Experimental Animals and their Management}

Twenty intact male yearling Horro sheep were purchased from the nearby local market. Age was determined by dentition and information obtained from the owner. The animals were used in a digestibility trial of 10 days followed by a feeding trial of 90 days. The experimental animals were de-wormed with albendazole against common internal parasites and sprayed with deiazinon against common external parasite, and vaccinated against common diseases in the area like ovine pasteurellosis, sheep pox and anthrax with $1 \mathrm{ml}$ ovine pasteurellosis vaccine, $1 \mathrm{ml}$ sheep pox vaccine and $1 / 2 \mathrm{ml}$ anthrax vaccine per sheep, during the quarantine period of 21 days, which was followed by an adaptation period of 15 days to the experiment feed and procedure. All animals were housed in individual pens throughout the experiment.

\section{Experimental Design and Treatments}

The experimental design was randomised complete block design (RCBD) that consists of four treatments. The treatments were supplementation of graded levels of wild silver leaf desmodium to natural pasture hay. The animals were blocked based on initial live weight into five blocks of four animals per block. The live weights of animals were determined by two consecutive weighing after overnight fasting. The four treatments were randomly assigned to each experimental animal in a block. The experimental design used is therefore, completely randomized block design.

Table 1 Experimental treatments

\begin{tabular}{lcc}
\hline Treatments & \multicolumn{1}{c}{ Experimental Feeds } \\
\cline { 2 - 3 } & Natural pasture hay (g/head/day) & $\begin{array}{c}\text { Desmodium } \\
\text { (g/head/day) }\end{array}$ \\
\hline Treatment 1 & Ad libitum & 0 \\
Treatment 2 & Ad libitum & 200 \\
Treatment 3 & Ad libitum & 300 \\
Treatment 4 & Ad libitum & 400 \\
\hline
\end{tabular}

\section{Growth Trial}

The growth trial was conducted for 90 days. All animals in the respective treatments used in the digestibility trial were used for growth trial too. There was no randomization of animals, i.e. animals used for digestibility were maintained in the respective treatment. During this period, the following data were collected.

\section{Body weight gain}

Initial body weight of animals was determined by taking the mean of the two consecutive weights after overnight fasting and subsequent body weight measurements were made at ten days' interval throughout the experimental period. Average daily body weight gain was calculated by dividing the weight difference by the number of feeding days. Feed conversion efficiency was estimated as a ratio of daily body weight gain and daily dry matter intake.

\section{Statistical Analysis}

Data collected was analyzed using the General Linear Model procedure of SAS (SAS, 2008). Treatment means were compared using Tukey adjustment. The model used for data analysis was

$\mathrm{Yij}=\mu+\mathrm{t}_{\mathrm{i}}+\mathrm{b}_{\mathrm{j}}+\mathrm{e}_{\mathrm{ij}}$

Where: $y_{i j}=$ response variable 


$$
\begin{gathered}
\mu=\text { overall mean } \\
t_{i}=\text { treatment effect } \\
b_{j}=\text { block effect } \\
\text { eij }=\text { random error }
\end{gathered}
$$

\section{RESULTS AND DISCUSSIONS}

\section{Chemical Composition of the Experimental Feeds}

The results of the chemical composition of wild silver leaf desmodium and hay (offered and refused) are shown in Table 2. The CP content of silver leaf desmodium in the current study was comparable with $17.5 \% \mathrm{CP}$ reported by Taye (2004)) for samples of silver leaf desmodium collected from different sites, but higher than the CP Content of $10.2 \%$ reported by Negussie (2008). The OM was lower than the OM value of 89.1 reported by Ngussie (2008) for desmodium. The NDF component is higher than the NDF content of 50.9\% reported by Taye (2004). The ADF and ADL content is lower than the ADF and ADL value of $38.3 \%$ and $8.3 \%$ reported by Taye (2004). The high ash content of silver leaf desmodium used in the current study implies that it contains enough amounts of minerals.

The hay used in the present study has DM content, which was comparable to the DM contents of 91.8\%, 91.4, 91.6, and 91.8\% reported by Asnakew (2005), Mulu (2005), Bimrew (2008), and Amansisa (2010), respectively, but slightly lower than $92.7,92.2 \%$, and 92.5 reported by Jemberu (2008), Wondwoson (2008), and Simachew (2009), respectively. The OM of hay in the present study was lower than the OM value of $89.8 \%, 80.4,88.5$, and 77.9 reported by Abebaw (2007), Bimrew (2008), Simachew (2009), and Amansisa (2010), respectively. The CP content of hay offered to the experimental animals in the current study is higher than $4.2 \%, 6.6 \%, 6.9 \%$, and $7.9 \%$ CP reported by Mulu et al. (2008), Simret and Solomon (2008), Simachew (2009), and Amansisa (2010), respectively. But it is comparable to the value of 9.2\% CP reported by Bimrew (2008). It has been noted that CP value ranging from $7-7.5 \%$ is needed to satisfy maintenance requirement of ruminant animals (Van Soest, 1982). Hence, the CP content of the mixed sward grass hay used in the current study is above the value demanded for maintenance requirements of sheep.

Table 2 Chemical composition of the experimental feeds (nutrients are as percent dry matter)

\begin{tabular}{lcclllll}
\hline Parameter & \%DM & OM & CP & NDF & ADF & ADL & ASH \\
\hline Feed offered & & & & & & & \\
Hay & 91.2 & 75.5 & 9.3 & 60.8 & 32.6 & 6.2 & 15.7 \\
Desmodium & 89.8 & 77.8 & 16.3 & 57.6 & 32.2 & 9.8 & 12 \\
Feed refusal & & & & & & & 9.3 \\
Hay (T1) & 90.2 & 80.9 & 6.1 & 65.6 & 35.6 & 6.9 & 12 \\
Hay (T2) & 90.1 & 79.4 & 6.4 & 66.6 & 42.6 & 6.8 & 15.8 \\
Hay (T3) & 90.1 & 75.6 & 5.8 & 63.6 & 34.8 & 11 & 15.8 \\
Hay (T4) & 90.4 & 74.6 & 6 & 61.8 & 33.8 & 12 & 9.8 \\
Desmodium (T2) & 90.2 & 80.5 & 8.6 & 58.6 & 34.8 & 16 & 14.4 \\
Desmodium (T3) & 90.3 & 70.5 & 11.4 & 59.6 & 36.6 & 14.6 & 15.5 \\
Desmodium (T4) & 90.1 & 75.7 & 12 & 59 & 33.8 & 15.8 & 15 \\
\hline AD & & & & & & \\
\hline
\end{tabular}

$A D F=$ acid detergent fiber $; A D L=$ acid detergent lignin; $C P=$ crude protein; $D M=$ dry matter; $N D F=$ neutral detergent fiber; $O M=$ organic matter; $T 1=$ natural pasture hay alone; $T 2=$ natural pasture hay $+200 \mathrm{~g}$ wild silver leaf Desmodium; T3= natural pasture hay $+300 \mathrm{~g}$ wild silver leaf Desmodium; $T 4=$ natural pasture hay $+400 \mathrm{~g}$ wild silver leaf Desmodium.

he higher CP content of hay in the current study might be attributed to the good environmental condition in which the grass was grown, proper drying of the hay, early harvesting time, and the observed better mixtures of legumes. Forage maturity stage at harvest is identified as the most important factor affecting the composition and nutritive value of pastures (Adane, 2003). The same authors described that the CP content of most grass species is adequate to meet minimum nutritional requirements for livestock if harvested at early stage, but $\mathrm{CP}$ content declines below this requirement at latter stages of harvesting. Based on the study conducted to compare the cutting dates on chemical composition of forages, Kidane (1993) also noted that early harvested hay gave high CP percentage than delayed harvest. However, at early age, the digestible crude protein (DCP) and total digestible nutrient (TDN) values of the legumes are very high, but the DM yield per hectare is very low (Ranjhan, 1980) indicating the need to balance for this phenomenon.

The NDF component of hay used in the current study is lower than the NDF content of $74.2 \%, 69.7 \%, 67.2 \%$, and 71.8\% reported by Simret and Solomon (2008), Bimrew (2008), Simachew (2009), and Amansisa (2010), respectively. Pond e al. (1995) noted that NDF portion of feed is only partially digestible by any species of animals, but can be used to greater extent by ruminants, which depend on microbial digestion for utilization of most fibrous plant component. The ADF content of hay used in the present experiment was lower than the ADF content of 38.4 and 46.4\% reported by Bimrew (2008) and Simachew (2009). Feed that contained lower proportion of ADF have better availability of nutrient due to ADF being negatively correlated with feed digestibility (McDonald et al., 
2002). The ADL content of hay used in the present experiment was lower than the ADL content of 11.0, 9.8 and 9.0\% reported by Bimrew (2008), Simret and Solomon (2008) and Simachew (2009), respectively. The DM, OM, $\mathrm{CP}, \mathrm{ADF}$, ash and ADL content of the hay refusals were almost similar among all treatments. This may be due to the feeding habits of sheep which selected the most nutritious parts of the grass such as leaves and shoots and left the relatively non-edible parts like stems in similar fashion among treatments. The higher the NDF and or the ADF composition of a feedstuff, the lower the nutritive value of that feedstuffs and vice versa (Beyene, 1976). The chemical composition of the hay used in this experiment could be characterized by its acceptable CP (9.3\%), NDF $(60.8 \%)$, which is lower than the minimum (45-65\%) reported to affect intake and digestibility (Singh and Oosting, 1992 ) and relatively lower ADF (32.6\%) contents. This low content of NDF and ADF may imply high intake and digestibility of the basal diet

\section{Body Weight Change and Feed Conversion Efficiency}

The body weight change, average daily gain (ADG), and feed efficiency of Horro sheep fed basal diet of natural pasture hay and graded level of silver leaf desmodium are given in Table 5. The final body weight of the sheep in the control group (T1) was lower $(\mathrm{P}<0.01)$ than final body weights of sheep fed graded level of wild silver leaf desmodium at all levels. Among the groups supplemented with wild silver leaf desmodium hay the lower and medium supplemented groups ( $\mathrm{T} 2$ and $\mathrm{T} 3)$ had lower $(\mathrm{P}<0.01)$ final body weights than the highest level (T4). In accordance with the variations in the final weights of sheep fed the experimental diets, there were also significant $(\mathrm{P}<0.01)$ difference in average daily weight gain $(\mathrm{ADG})$ of sheep in the different treatments. Accordingly, sheep fed the basal diet, that is natural pasture hay alone (T1), has significantly lower $(\mathrm{P}<0.01)$ ADG than sheep supplemented with wild silver leaf desmodium in addition to ad libitum consumption of natural pasture hay diets (T2, T3 and T4). There were also significant $(\mathrm{P}<0.01)$ differences in ADG among sheep fed the different levels of wild silver leaf desmodium as a supplement to natural pasture hay. Accordingly, T4 has the highest ADG as compared to T2 and T3 which are not statistically different from each other Similar to the current study, Mtenga and Mafweress (1992) showed that supplementation increased DM intake of sheep fed hay supplemented with lablab meal and maize bran, which correspondingly increased body weight gain in sheep. The increase in ADG by sheep supplemented with wild silver leaf desmodium agrees with Kariuki et al. (1999) who reported that heifers fed natural pasture hay as a sole diet gained $0.41 \mathrm{~kg}$ per day, while those on natural pasture hay intercropped with desmodium, natural pasture hay alone, and Napier grass supplemented with desmodium hay gained $0.45,0.52$ and $0.42 \mathrm{~kg}$ per day, respectively showing the positive effect of desmodium as a supplement to grass hay.

Table 5 Body weight parameters and feed conversion efficiency of Horro sheep fed natural pasture hay and graded level of wild silver leaf desmodium

\begin{tabular}{lllllll}
\hline Parameter & T1 & T2 & T3 & T4 & SEM & SL \\
\hline IBW & 18.1 & 18.2 & 18.4 & 18.6 & 0.36 & Ns \\
FBW & $19.8^{\mathrm{c}}$ & $21.6^{\mathrm{b}}$ & $22.3^{\mathrm{b}}$ & $24.8^{\mathrm{a}}$ & 0.48 & $* * *$ \\
BWG & $1.4^{\mathrm{c}}$ & $3.5^{\mathrm{b}}$ & $4.1^{\mathrm{b}}$ & $6.2^{\mathrm{a}}$ & 0.58 & $* * *$ \\
ADG & $15.6^{\mathrm{c}}$ & $38.9^{\mathrm{b}}$ & $45.6^{\mathrm{b}}$ & $68.9^{\mathrm{a}}$ & 6.47 & $* * *$ \\
FCE & $0.023^{\mathrm{b}}$ & $0.054^{\mathrm{b}}$ & $0.059^{\mathrm{a}}$ & $0.080^{\mathrm{a}}$ & 0.0080 & $* *$ \\
\hline
\end{tabular}

$a, b, c=$ letters in the same row having different superscript are significantly different; $A D G=$ average daily body weight gain; $B W=$ body weight; $F C E=$ feed conversion efficiency; IBW= initial body weight; FBW= final body weight; T1=natural pasture hay ad libitum; T2= natural pasture hay ad libitum $+200 \mathrm{~g}$ wild silver leaf Desmodium; $T 3=$ natural pasture hay ad libitum $+300 \mathrm{~g}$ wild silver leaf Desmodium; $T 4=$ natural pasture hay ad libitum $+400 \mathrm{~g}$ wild silver leaf Desmodium.

The current finding revealed that supplementation with legume forage increased the average daily body weight gain. However, the gain attained is lower than that reported for small ruminants supplemented with different concentrate diets in previous studies (For example, Asnakew, 2005; Abebaw, 2007; Mulat, 2006; Fentie, 2007). Demissie et al. (1987) reported a daily body weight gain of $72 \mathrm{~g}$ in yearling Horro lambs supplemented with 300 $\mathrm{g} /$ day concentrate, which is only slightly higher than the gain obtained in groups supplemented with the highest level of the legume forage in the present study. On the other hand, Solomon (1996) reported a range of 90-131 g/day gain in Horro sheep under free grazing. Melese et al. (2001) indicated that Horro lambs have the potential of gaining more when they are managed under improved forage and concentrate supplementation. The authors reported a range of 30-121 g/day gain in Horro lambs when natural hay is supplemented with $216 \mathrm{~g}$ ground maize and 150 noug seed cake under indoor feeding condition. Gebregziabher et al. (2002) also noted that Horro rams perform better in terms of body weight gain when supplemented either concentrate or herbaceous legumes.

Feed conversion efficiency was higher $(\mathrm{P}<0.001)$ in the order of $\mathrm{T} 3=\mathrm{T} 4>\mathrm{T} 2=\mathrm{T} 1$. The results of this study explicitly revealed the advantages of supplementation of legume hay to natural pasture based diet in improving total DM, OM and CP intakes, digestibility, live weight gain, and feed conversion efficiency. In general, the supplemented sheep had better body weight gain and nutrient intake than the non-supplemented groups. This is an attribute of better availability of nutrients to animals', particularly crude protein, which is in line with the 
established fact that supplementation results in improved animal performance in several ways, such as by providing essential nutrients for rumen microorganisms, enhancing the microorganism activities in the rumen and providing nutrients for the sheep (Van Soest, 1994). For the supplemented group of sheep in the current study, a gradual and continuous increment of weekly body weight was observed at higher rate than that of the control group.

Figure 2 Trends in body weight change across the experimental period for Horro Sheep fed Natural pasture hay and graded level of wild silver leaf desmodium

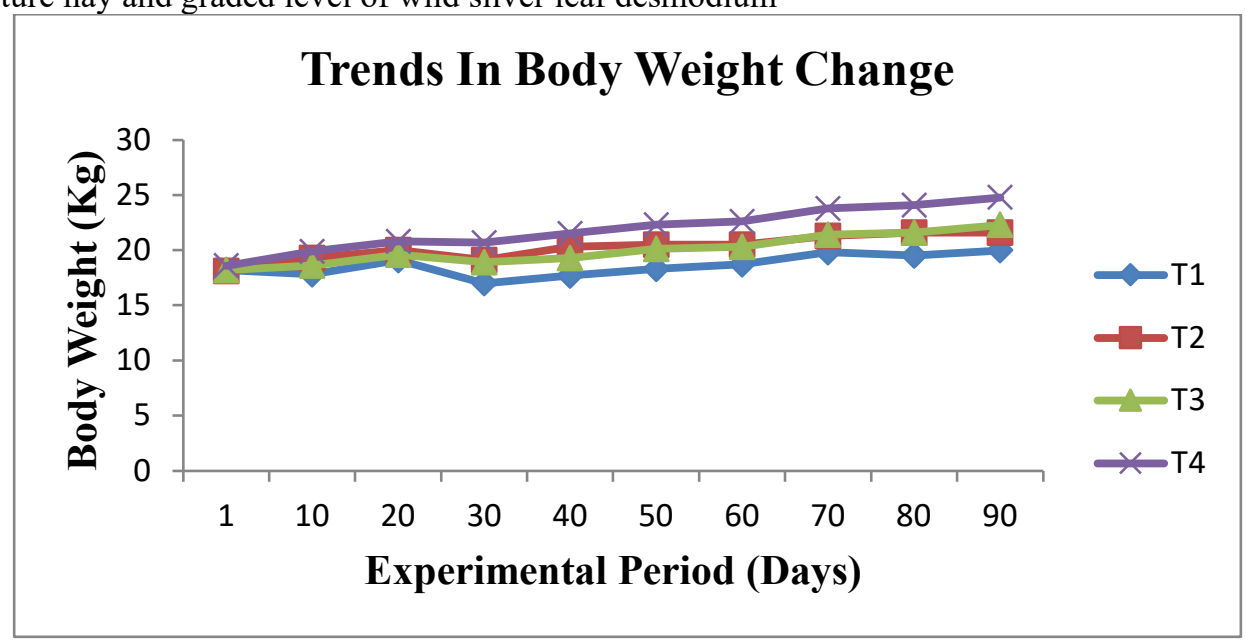

$T 1=$ natural pasture hay alone ad libitum; $T 2=$ Natural pasture hay ad libitum $+200 \mathrm{~g}$ wild silver leaf Desmodium; $T 3=$ Natural pasture hay ad libitum $+300 \mathrm{~g}$ wild silver leaf Desmodium; $T 4=$ Natural pasture hay ad libitum +400 $g$ wild silver leaf Desmodium.

\section{CONCLUSIONS}

Generally, the results of the study revealed that the supplementation of legumes in improving growth and body weight change and nutrient utilization than feeding sole natural pasture hay due to better availability of nutrients to animals' particularly crude protein. Therefore, supplementation with $400 \mathrm{~g} / \mathrm{day}$ desmodium hay higher improved Average daily body gain(ADG) of sheep. Hence, in the present study, it was concluded that supplementation of hay with $400 \mathrm{~g}$ /day/head is biologically efficient in feeding of growing Horro sheep.

\section{ACKNOWLEDGEMENTS}

Above all, loving, kindness and faithfulness of the Almighty God in bestowing health, strength, patience and protection throughout the study period is highly appreciated and my thanks pass to my lovely wife Lensa Kumara Najo and my son Raga Jalel Fikadu since they are psychologically support me throughout the research work period.

\section{REFERENCES}

Abebe Hailu, 2008. Supplementation of graded levels of concentrate mixture on feed intake, digestibility, live weight and carcass characteristics of Washera sheep fed urea treated rice straw.

Adane Kitaba, 2003. Effect of harvesting and fertilizer application on dry matter yield and quality of natural grass land in the high land of North Shoa. An MSc Thesis Presented to School of Graduate Studies Alemaya University, Alemaya Ethiopia.96p

Amansisa Eresso(2010) Effect OF supplementation of different levels of dried 'girawa' (Vernonia amygdalina) foliage and crushed maize grain mixtures on feed intake, digestibility and body weight change Horro sheep feed a basal diet natural pasture hay.

Asnakew Awoke, 2005. Feedlot fatting performance and carcass characterization of intact male Hararghe highland goat feed different level of hay to concentrate ratios. An MSc Thesis submitted to the department of animal science, School of Graduate studies of Alemaya University, 65p

Beyene Chichaibelu, 1976. Laboratory evaluation and estimation of nutritive value of some Ethiopian feedstuff and formula feeds plus animal evaluation of noug seed cake (Guizotia abyssinica). An MSc Thesis Presented to the Faculty of the Graduate School of Cornell University for the Degree of doctrine of philosophy. 135p

Ben Salem, H. H.P.S. Makkar and A. Nefzaoui, 2003. Towards better utilization of nonconventional feed resources by sheep and goats in some African and Asian countries.

Bimrew Asmare, 2008. Supplementation of Different levels of Rice Bran and Noug seed cake Mixtures on nutrient utilization of Farta sheep fed natural pasture hay as a basal diet. An MSc Thesis presented to the School of Graduate Studies of Haramaya University. 68p

CSA, 2004. Central Statistics Authority of the Federal Democratic Republic of Ethiopia. Agricultural Sample 
Survey 2003/2004. II. Report on livestock and livestock characteristics. Statistical bulletin 302. pp. 29-30.

CSA (Central statistical agency (2012/13); federal democratic republic of Ethiopia central statistical agency agricultural sample survey volume II report on livestock and livestock characteristics 2012/13 [2005 E.C.]

Demissie Tesfaye, kassahun Awgichew and Yohannes Gojjam, 1987. Comparison of castrated and entire Horro male lambs for growth and fattening ability under various feeding regimes.

Fentie Bishaw, 2007. Feed utilization and live weight change of Farta Sheep Supplemented with noug seed (Guizotia abyssinica) cake, wheat bran and their mixtures. An MSc Thesis presented to the School of Graduate Studies of Haramaya University. 87p

Gebregziabher Gebreyohannes, Dirriba Geleti, Lemma Gizachew, Yohannes Gojam and Gemeda Duguma, 2002. Effect of noug cake and Sesbania sesban supplementation on the growth performance and carcass characteristics of Horro rams. Proceeding of the fourth National Conference of the Ethiopian Society of Animal Production (ESAP). pp. 180-192

Kariuki, J.N., G.K. Gitau, C.K. Gachuiric, S. Tamminga, J.M.K. Muia, 1999. Effect of Supplementing Napier grass with Desmodium and Lucerne on DM, CP and NDF intake and Weight gains in dairy heifers. Livestock Production Science 60: 81-88

Jemberu Dessie, 2008. Effects of Supplementation of Simada Sheep with Graded levels of Concentrate cake on feed intake, Digestibility and body weight parameters. An MSc Thesis Presented to the School of Graduate Studies of Haramaya University. 68p

Markos Tibbo, 2006. Productivity and health of indigenous sheep breeds and crossbreds in the Central Ethiopian Highlands. Doctoral Thesis. Swedish University of Agricultural Science, Department of Animal Breeding and Genetics. Uppsala, Swedin. 11pp

Melese Abdisa, Dirriba Geleti, Lema Gizachew, Temesgen Dirriba and Adane Hirpa, 2001. The effect of improved forages and /or concentrate supplementation on live weight of horro lambs and growing bulls. pp. 259-265. In: Proceeding $9^{\text {th }}$ Annual Conference of the Ethiopian society of Animal Production (ESAP), held in Addis Ababa, Ethiopia

Mulat Alem, 2006. Effects of supplementing different protein sources on feed intake and live eight gains of local sheep fed on finger millet (Eleucine coracana) straw basal diet. An Msc Thesis submitted to the Departement of Animal Science, School of graduate Studies. Alemaya University. 52p

Mulu Moges, Berehan Tamir and Alemu Yami, 2008. The effect of Grass Hay with different level of Brewer's Dried Grain on feed intake, digestibility and body weight gain intact Wogera lumbs. East African J. of Sci. Vol.2, Num.2. June 2008. Issn 1992-0407, pp 105-110.

Mtenga L.A and WD, Mafwere, 1992. Experience in protein supplementary feeding of weaned rams and goat kids in Tanzania: The issue of dietary energy. In: Rey B.; Lebbie, SHB and Reynolds. L. (eds). Small ruminant research development in Africa. Nairobi, Kenya. Pp387

Negussie Mohammed idris(2008): effects of supplementation of napier grass with greenleaf desmodium or lablab on feed intake, digestibility and live weight change of washera sheep Proceedings IAR. Second National Livestock Improvement conference in Ethiopia. Addis Ababa, Ethiopia, 24-26, February 1987. Institute of Agricultural Research

Pond, K.R., C.D. Church and G.W. Pond, 1995. Basic Animal Nutrition and Feeding. $4^{\text {th }}$ ed. John Willey and Sons. New York. 615p. Report on area and production of Belg season crops for Private Peasant Holdings.'

Singh,G.P. and S.J.Oosting, 1992. A model for describing the energy value of straws. Indian Dairyman XLI: $322-$ 327

Simachew Gashaw, 2009. Effects of Supplementation with maize bran, Noug seed (Guizoitia abyssinica) cake and their mixtures on feed utilization and carcass characteristics of Washera sheep fed hay. An MSc Thesis presented to the School of Graduate Studies of Haramaya University. 25-26pp

Solomon Abegaz 1996. Performances of ewes lambing at two different periods of rainy season. Pp. 86-92. Proceedings of the 4 th National Conference of Ethiopian Society of Animal eduction (ESAP). Addis Ababa, Ethiopia, 18-19 April1996

Taye Bayable,2004. Effects of Days of Harvesting on Yield, Chemical Composition, and InVitro Organic Matter Digestibility of Pennisetum purpureum Sole or Intercropped with Desmodium uncinatums or Lablab purpureus. MSC Thesis, Alemaya University

Van Soest, P.J.1982. Nutritional ecology of the ruminant.O and B books. Corvallis, Oregon

Wondwosen Alemu, 2008. Effects of Supplementing hay from natural pasture with oilseed cakes on feed intake, digestibility and body weight change of Sidama goats. An MSc Thesis presented to the School of Graduate Studies of Haramaya University, Ethiopia. 62p 